\title{
Caddo Sherds from the Hudnall-Pirtle Site (41RK4) in the Buddy Jones Collection at the Gregg County Historical Museum
}

Timothy K. Perttula

Heritage Research Center, Stephen F. Austin State University

Follow this and additional works at: https://scholarworks.sfasu.edu/ita

Part of the American Material Culture Commons, Archaeological Anthropology Commons, Environmental Studies Commons, Other American Studies Commons, Other Arts and Humanities Commons, Other History of Art, Architecture, and Archaeology Commons, and the United States History Commons

Tell us how this article helped you.

This Article is brought to you for free and open access by the Center for Regional Heritage Research at SFA ScholarWorks. It has been accepted for inclusion in Index of Texas Archaeology: Open Access Gray Literature from the Lone Star State by an authorized editor of SFA ScholarWorks. For more information, please contact cdsscholarworks@sfasu.edu. 
Caddo Sherds from the Hudnall-Pirtle Site (41RK4) in the Buddy Jones Collection at the Gregg County Historical Museum

\section{Creative Commons License}

(c) (1) (8)

This work is licensed under a Creative Commons Attribution-NonCommercial 4.0 International License 


\title{
Caddo Sherds from the Hudnall-Pirtle Site (41RK4) in the Buddy Jones Collection at the Gregg County Historical Museum
}

\author{
Timothy K. Perttula
}

\section{INTRODUCTION}

Buddy Calvin Jones, a resident of Longview, Texas, conducted excavations in 1958 and 1959 of an unknown extent at the Hudnall-Pirtle site (41RK4), a well-known and significant Early Caddo (ca. A.D. 900-1200) multiple mound center on a Sabine River alluvial terrace in Rusk County, Texas (Bruseth and Perttula 2006). The site is now owned by The Archaeological Conservancy as a Caddo archaeological preserve. Caddo sherds from the site are in the Jones collection curated at the Gregg County Historical Museum, and recently I had an opportunity to examine this collection. This paper puts the findings of that examination on record.

\section{THE COLLECTIONS}

Jones variously referred to the site as the Hudnall site, Easton, the Cherokee Bayou Mound, and the North Mound, and he has collections from each area, but they are all believed to pertain to what is now known as the Hudnall-Pirtle site. The work by Jones included Trenches A and B in a village area (the village area at the site covers ca. 60 acres, so unfortunately a more precise provenience of this material cannot be specified, nor is the size and depth of the trench known), an Area I in the North Mound (likely Mound C, see Bruseth and Perttula 2006:Figure 2), and a $1 \mathrm{~W}$ trench in what he called the Easton or Cherokee Bayou Mound site.

Hudnall (accession nos. 03-08-810, Trench $A$, and 03-08-811, Trench $B$ in village area, August and September 8, 1959, 03-08-814, Trench B [1-2 ft.], 03-08-815, Pottery Concentration)

The September 1959 Trench A excavations by Jones recovered 36 sherds, including three plain rims and 19 plain body sherds. The incised sherds $(\mathrm{n}=5)$ from this area include one rim with at least two horizontal incised lines, a Davis Incised or Kiam Incised (cf. Suhm and Jelks 1962:Plate 45a, c-d) body sherd with very closely spaced parallel incised lines, two body sherds with widely-spaced parallel incised lines, and another sherd with a single straight incised line on it.

Four sherds from this work at Trench A have incised and punctated decorative elements. The first is from a Pennington Punctated-Incised carinated bowl and has incised triangles on the rim filled with circular punctations (cf. Suhm and Jelks 1962:Plate 61i); the second Pennington Punctated-Incised sherd is a rim with a broad diamond-shaped incised zone filled with cane punctations (cf. Suhm and Jelks 1962:Plate 61d). The other two incised-punctated sherds are from Coles Creek Incised, var. Coles Creek vessels (Brown 1998:9; Phillips 1970:70). These sherds have horizontal incised lines on the rim, with a row of triangular-shaped impressed punctations immediately below the lowest horizontal incised line. Bruseth and Perttula (2006:88-89 and Figure 27) recovered similar Coles Creek Incised sherds from several village areas at the Hudnall-Pirtle site.

The three remaining utility wares from Trench A have punctated decorations. A carinated bowl sherd has at least two rows of fingernail punctates on the rim panel, and a body sherd has a single row of tool punctates. The third is an interesting rim from a vessel with a scroll motif - similar to scrolls noted on some Crockett Curvilinear Incised vessels (cf. Suhm and Jelks 1962:Plate 17f-i) - that is executed solely with tool punctates rather than with incised scroll elements filled with punctations.

Trench A has two engraved fine ware sherds, both rims. The first is a well-executed Holly Fine Engraved sherd with closely-spaced vertical and diagonal sets of engraved lines divided by a 
large triangular excised area (cf. Suhm and Jelks 1962:Plate 39a-b, e, g, i). The second rim has a single horizontal engraved line under the lip and widely spaced opposed engraved lines on the rim panel.

The Trench B sherds were collected by Jones in August 1959 (Trench B village, Area 1, 10-30 inches). This is a diverse lot of 67 sherds and two ear spool sherds. The plain sherds include two rims and 44 body sherds, among them two body sherds from a bottle. One of the sherds in this collection is a plain sandy paste rim sherd, Goose Creek Plain, var. unspecified, indicative of some limited use of this locality in Woodland period times. Another sherd is from a rim peaked bowl jar that has horizontal brushing on the rim and a row of triangular tool punctates under the lip. Because brushed vessels are apparently only common in Caddo sites in this part of the Sabine River basin after ca. A.D. 1200, this particular sherd is evidence of use after that time; the recovery of two arrow points that resemble the Perdiz and Bassett points from the Well Pad village area also mark this transitory late use of the HudnallPirtle site (Bruseth and Perttula 2006:102).

The utility ware sherds from the Trench B village include incised $(n=5)$, incised-punctated $(n=6)$, and punctated $(n=5)$ sherds. Two of the incised sherds may be from Davis Incised vessels, as they have horizontal incised lines on the rim; one of these is a carinated bowl. Three other incised body sherds have closely-spaced parallel incised lines. The punctated body sherds have either tool $(n=4)$ or fingernail punctates, either in rows or randomly placed across the vessel body.

The first incised-punctated sherd from the Trench B village is a Coles Creek Incised, var. Coles Creek body sherd with a row of triangular tool punctations below at least one horizontal incised line. The second has an incised triangle that is bisected with two closely-spaced vertical incised lines; there is at least one tool punctate within the incised triangle. Three others, all body sherds, have a straight (or triangular?) incised line adjacent to a zone of punctations, either tool $(n=2)$ or cane $(n=1)$. The last incised-punctated body sherd has at least two widely-spaced parallel (likely oriented horizontally around the vessel rim) incised lines with a single row of triangular-shaped tool punctations between the lines; these sherds are well represented in the larger Hudnall-Pirtle ceramic assemblage described by Bruseth and Perttula (2006:87 and Figure 26d).

Fine wares in this Trench B collection are limited to two Holly Fine Engraved sherds and a carinated bowl rim with diagonal engraved lines. One of the Holly Fine Engraved sherds is from a carinated bowl (cf. Suhm and Jelks 1962:Plate 40a) and the other, with very closely-spaced engraved lines, is from a bottle (cf. Suhm and Jelks 1962:Plate 40g).

The clay ear spools are plain, from different sets (based on their different sizes), with pronounced flanges along the exterior edges of the spool itself. Virtually identical Early Caddo style ear spools were found in village areas by Bruseth and Perttula (2006:Figure 29d-e).

There are only two sherds from accession no. 03-08-814, Trench B, at the Hudnall locality. One of these is a plain body sherd, while the other may have a poorly preserved stamped (?) decoration with parallel incised lines that cross over the stamping.

The "pottery concentration" in Trench B (14 inches in depth) includes 63 sherds, all apparently from the same grog-tempered vessel. The few rims have a single horizontal incised line also immediately under the vessel lip; the remainder of the sherds are plain.

\section{North Mound, Area I (accession no. 03-08-816)}

Jones' work in the North Mound led to the recovery of 72 plain sherds and 14 decorated body sherds, all from utility wares. The plain wares include a single plain rim, 67 plain body sherds (among them a sherd from a carinated bowl), and four thick grog-tempered body and base sherds that may be from a grog-tempered Williams Plain vessel. Among the utility ware are body sherds with punctated $(n=5)$, incised-punctated $(n=2)$, and incised $(n=7)$ decorative elements.

There are both fingernail $(\mathrm{n}=2)$ and tool $(\mathrm{n}=2)$ punctated sherds from the North Mound. The punctations occur either in rows $(n=3)$ or are randomly placed $(n=2)$ across the vessel sherd surface.

The first incised-punctated body sherd has at least three widely-spaced parallel (likely oriented horizontally around the vessel rim) incised lines with a single row of triangular-shaped tool punctations between the lines; similar sherds are present in the Hudnall locality (see above). The second incised-punctated body sherd is from a Crockett Curvilinear Incised vessel; it has an incised circle filled with tool punctates.

Four of the seven incised sherds from the North Mound have only a single straight incised line. Two others have closely-spaced parallel incised lines, and 
the last incised sherd is from a carinated bowl that has closely-spaced vertical incised lines on the rim panel. This particular sherd may be from a Dunkin Incised vessel (cf. Suhm and Jelks 1962:Plate 19d, h).

\section{Cherokee Bayou Mound site, Easton (accession no. 03-08-817)}

The materials in this accession collection include 27 plain body sherds and 13 decorated sherds, all from utility wares. Four of the sherds (one rim and three body sherds) may be from a Pennington Punctated-Incised beaker (cf. Suhm and Jelks 1962:Plate 61c) with vertical incised panels and vertical zones filled with tool punctations. There are two rims from different Davis Incised vessels that have horizontal incised lines; a third rim has a single deeply horizontal incised line midway down the rim, and there is a body sherd with multiple and closely-spaced incised lines on it.

Three sherds have punctated decorative elements. The first of these has two rows of tool punctations placed midway down the rim, while the second rim has at least three rows of triangular-shaped tool punctations. One body sherd has random or freely placed linear punctations covering the sherd surface. One grog and bone-tempered body sherd from this collection has a series of vertical rows of pinching, and a rim has a row of small circular punctations just below the vessel lip and above a single horizontal incised line.

\section{Easton \\ (accession nos. 03-08-812, 03-08-813)}

The sherds in this part of the collection were collected on January 18, 1958, and include sherds from a $1 \mathrm{~W}$ trench. They include 46 plain body sherds, one plain body sherd from a bottle, 10 base sherds, and a number of decorated sherds from fine ware and utility ware vessels.

Sherds from utility ware vessels include four Weches Fingernail Impressed, var. Weches body sherds (Stokes and Woodring 1981:184-185 and Figures 22n-q and 23a), one Coles Creek Incised rim with multiple horizontal incised lines, a Crockett Curvilinear Incised body sherd with semi-circular incised zones filled with small punctations, and a rim sherd with a horizontal incised panel filled with two rows of stab and drag punctations. Five body sherds have closely-spaced parallel incised lines, and there are 14 other body sherds with punctated elements. Nine of these have one or two rows of fingernail $(n=4)$ or tool $(n=4)$ punctations, one has opposed rows of tool punctations, and five have large circular tool punctations that apparently covered the vessel body.

The fine wares from this work comprise three rims with a single horizontal engraved line below the lip, another rim (from a peaked rim vessel) with at least two curvilinear engraved lines, and one Holly Fine Engraved carinated bowl sherd with closely-spaced vertical engraved lines on the rim panel adjacent to an excised area (cf. Suhm and Jelks 1962:Plate 40a). Three other body sherds have widely-spaced parallel engraved lines and another has a set of opposed engraved lines.

\section{SUMMARY AND CONCLUSIONS}

The presence of Holly Fine Engraved, Crockett Curvilinear Incised, Pennington Punctated-Incised, Davis Incised, and Coles Creek Incised sherds from these Buddy Jones collections, from several different contexts, at the Hudnall-Pirtle site indicate that the archaeological deposits he excavated into date to the Early Caddo period (ca. A.D. 900-1200). In general stylistic character, they are consistent with the kinds of decorated sherds found in the larger sherd assemblage discussed by Bruseth and Perttula (2006:82-95) from village and mound contexts at the site, and provide supplementary information about the nature of Early Caddo ceramics at this site in particular, and in this region in general.

A more detailed comparison of decorative methods (Table 1 ) tells much the same story, in that

Table 1. Comparisons of the decorated sherds from two collections from the Hudnall-Pirtle site.

\begin{tabular}{lcc}
\hline Decorative Method & THC work & BCJ work \\
\hline Incised & $31.3 \%$ & $30.0 \%$ \\
Punctated & $36.6 \%$ & $30.0 \%$ \\
Pinched & - & $1.0 \%$ \\
Incised-punctated & $10.3 \%$ & $23.0 \%$ \\
Brushed-punctated & - & $1.0 \%$ \\
Engraved & $21.9 \%$ & $14.0 \%$ \\
Slipped & - & $1.0 \%$ \\
\hline Totals & 681 & 100 \\
Plain/Decorated Ratio & 4.00 & 2.84 \\
\hline
\end{tabular}


incised, punctated, and incised-punctated utility wares dominate the ceramic assemblages in both collections, accounting for between 78.1-84\% of the decorated sherds. Fine wares comprise between $15-21.9 \%$ of the decorated sherds.

The generally high plain/decorated sherd ratios (see Table 1) are consistent with pre-A.D. 1200 Caddo ceramic assemblages in East Texas. Moreover, they indicate that plain vessels, or vessels where the decorative element is restricted primarily to the rim rather than to both the rim and the vessel body, are important parts of the Early Caddo Hudnall-Pirtle site ceramic assemblage.

\section{ACKNOWLEDGMENTS}

I want to thank Patti Haskins, volunteer at the Gregg County Historical Museum, for bringing this sherd collection to my attention, and facilitating its study. Bo Nelson assisted with the analysis of the collection.

\section{REFERENCES CITED}

Brown, I. W.

1998 Decorated Pottery of the Lower Mississippi Valley: A Sorting Manual. Mississippi Archaeological Association and Mississippi Department of Archives and History, Jackson.
Bruseth, J. E. and T. K. Perttula, with contributions by G. J. Fritz and B. C. Yates

2006 Archeological Investigations at the Hudnall-Pirtle Site (41RK4): An Early Caddo Mound Center in Northeast Texas. Caddo Archeology Journal 15:57158.

Phillips, P.

1970 Archaeological Survey in the Lower Yazoo Basin, Mississippi, 1949-1955. Papers of the Peabody Museum of Archaeology and Ethnology, Volume 60. Peabody Museum, Harvard University, Cambridge.

Stokes, J. and J. L. Woodring

1981 Native-Made Artifacts of Clay. In Archeological Investigations at the George C. Davis Site, Cherokee County, Texas: Summers of 1979 and 1980, edited by D. A. Story, pp. 135-238. Occasional Papers No. 1. Texas Archeological Research Laboratory, The University of Texas at Austin.

Suhm, D. A. and E. B. Jelks (editors)

1962 Handbook of Texas Archeology: Type Descriptions. Special Publication No. 1, Texas Archeological Society, and Bulletin No. 4, Texas Memorial Museum, Austin. 